\title{
PROFISSÕES DE MEDO
}

0 medo é um sentimento inerente à maioria das atividades profissionais. Em algumas, contudo, ele chega a limites absurdos, os quais são capazes de bloquear inteiramente a própria atividade. Mesmo assim, a maioria dos profissionais não sucumbe. A pergunta é: como eles conseguem? POR SEIJI UCHIDA

0 medo é uma emoção presente em diversas atividades, relacionado com situações em que há algum risco envolvendo a pessoa ou alguém conhecido. Dependendo de sua intensidade e extensão, o medo pode imobilizar psiquicamente um profissional e, no limite, inutilizá-lo para o trabalho. Ao mesmo tempo, sentir essa emoção é necessário para que o indivíduo possa avaliar e dimensionar o risco - preparando-se para se defender, evitar ou fugir daquilo que o coloca em perigo - e, nesse sentido, fundamental para o desenvolvimento da atividade do profissional, em particular do policial.

Este artigo tem como objetivo apresentar e discutir os resultados de uma pesquisa realizada junto aos soldados da PM que fazem o policiamento ostensivo em São Paulo. Por meio das abordagens da psicopatologia e psicodinâmica do trabalho focalizaremos certos aspectos que consideramos "dimensões esquecidas" das organizações de trabalho.

Paradoxalmente, quando pedimos a um soldado que fale sobre o seu trabalho, raramente ele faz alguma referência ao medo. Quando questionado sobre esse sentimento, é comum o policial responder que não sente medo, que está habituado a lidar com o perigo. Essa ausência da consciência do medo é enigmática. Quando se esperava que o soldado manifestasse o medo de algum modo, dada a situação de risco a que essa profissão expõe, ele demonstra tranquilidade. Perguntamo-nos por quê? 
PERSPECTIVA ORGANIZACIONAL. Em função de dois episódios que abalaram a Policia Militar paulista - a morte de 111 detentos do Carandiru, em 1992, e a tortura e morte de civis no evento conhecido como Favela Naval, em 1997, quando foram registradas cenas em que um policial atira contra um homem após torturá-lo e alveja outro, localizado em um Gol - teve início um profundo processo de reestruturação da corporação, sob o comando do coronel PM Carlos Alberto Camargo, em 1997.

Com o processo de democratização do país e, principalmente, após a Constituição de 1988, a PM, na figura de alguns jovens oficiais, pesquisava uma nova estrutura para a instituição. O objetivo era deixar de ser a polícia repressiva e reativa dos tempos da ditadura militar e passar a ser uma polícia preventiva e respeitadora dos direitos humanos.

O cel. PM Camargo foi protagonista do processo de implementação efetiva desse novo ideário. De um lado, ele utilizou a corregedoria para identificar e punir todos aqueles que maculavam a imagem da organização. De outro, com o auxílio dos jovens oficiais auxiliares, a PM modificou o processo de seleção e formação do soldado, com ênfase numa nova concepção de segurança (Polícia Comunitária). Aumentou o período probatório para dois anos, podendo o candidato ser desligado caso não apresentasse as qualificações necessárias. 
PESQUISA E RESULTADOS. O processo de reestruturação é necessário para contextualizar a corporação e entender a fala dos sujeitos da pesquisa. Com a anuência do então secretário da Segurança Pública, Saulo de Castro Abreu Filho, e do comandantegeral, coronel PM Eliseu Éclair Teixeira Borges, realizamos entrevistas abertas individuais e grupais com soldados. A fala livre típica desse tipo de coleta de dados propiciou-nos um material rico para a compreensão do cotidiano desse profissional.

Dentre esse material, é possível focar a questão do medo, ou, como mencionado anteriormente, sua ausência. O conceito que permite elucidar o enigma dessa ausência é o de normalidade. Christophe Dejours, influente psicanalista francês, em vários textos afirma que a "normalidade" no trabalho é algo digno de atenção, pois muitos trabalhadores teriam razões de sobra para enlouquecer. Em vez de se desestabilizarem psicologicamente, o que vemos são trabalhadores produtivos $e$ eficientes, mesmo que às vezes paguem um preço elevado por isso na forma de sofrimentos diversos.

Para aquele psicanalista, a normalidade no trabalho é fruto de poderosos mecanismos de defesa, tanto individuais quanto coletivos. Ambos esses mecanismos visam a proteger mentalmente indivíduos e grupos de situações de trabalho enlouquecedoras. A normalidade é resultado da ação das forças desses mecanismos de defesa.

No caso dos policiais militares, vemos muito claramente o uso desses mecanismos, sobretudo se considerarmos que a situação de trabalho desses profissionais representa reais fatores de medo e perigo. Observamos que a principal defesa coletiva encontrada entre eles é a virilidade. Trata-se de um processo em que certos estereótipos da masculinidade são ressaltados e utilizados para fazer frente aos riscos e perigos que esse trabalho gera.

Coletivamente, os soldados sustentam, mutuamente, comportamentos e atitudes viris, e uma das facetas é a ausência do medo. O soldado que apresentar algum indício de medo será objeto de execração pública; sua masculinidade será posta em questão e, no limite, perderá a confiança do grupo, sendo tratado como alguém frouxo, "florzinha", não confiável e que na hora H colocará a vida dos companheiros em risco. Essa rede de proteção coletiva parece permitir aos soldados desempenhar suas funções e não sentir medo diante dos desafios que colocam em risco sua vida e a dos companheiros.

Cabe ressaltar que hoje existem na corporação tanto soldados antigos, selecionados antes de 1998, quanto novos, selecionados depois de 2000, quando, conforme comentamos, se inicia um novo processo de seleção. Isso torna a situação do trabalho complexa. Antes de 1998, o perfil desejado era o do típico "mocinho que caçava bandidos", um indivíduo destemido a serviço da proteção do Estado. Hoje, o perfil é de um soldado que age pensando na proteção da comunidade consciente dos direitos humanos e com uma nova estratégia de ação. Uma estratégia que evita o confronto e a troca de tiros. GESTÃO DO MEDO. Nossa pesquisa com soldados da PM nos permite pensar em algumas lições para os gestores. Pois eles, ao negarem a existência do medo - real ou imaginário - também lançam mão de mecanismos de defesa, os quais podem trazer consequências negativas. Portanto, 
entendemos ser fundamental uma atenção cuidadosa a esses aspectos da experiência do medo no trabalho (e das defesas contra ele).

Vamos apontar ao menos uma das questões cruciais para a gestão de pessoas: a exigência de virilidade pode levar o grupo a valorizar ações individuais. O sucesso numa ação perigosa de um soldado mais velho pode servir como fonte de identificação de todos, sendo tal sucesso vivido como sucesso do grupo. Quer dizer, como se as outras pessoas fossem também autoras daquela ação.

$\mathrm{Na}$ ausência da percepção ou consciência do medo, existe o risco de que o soldado se exponha a erros graves por não avaliar adequadamente a situação. A ausência da consciência do medo pode expor o indivíduo a riscos desnecessários. Mas é importante destacar que tal ausência não significa ausência de medo. Sua manifestação é que é proibida. Com isso, a pessoa sofre duplamente: pelo risco que corre e pela impossibilidade de manifestar e compartilhar seu medo. O mesmo vale para muitas situações de trabalho em nossas organizações, quando as pessoas não assumem seus medos, pois, se o fizerem, poderão ser percebidas como fracas e incapazes.

Para contornar essa situação, as estratégias de gestão de pessoas poderiam incluir a disponibilização de um espaço de discussão pública para que o grupo possa expressar livremente essas tensões ligadas ao medo sem necessariamente tocar na fragilidade delas e, ao mesmo tempo, discutir os riscos de forma honesta e sem censura. Esse espa- ço, em vez de reforçar a defesa, pode levar à cooperação, uma forma alternativa de relação coletiva.

Mas a condição básica para que isso ocorra é a criação de relações de confiança. Esse é o grande desafio do gestor. No caso em particular da polícia, uma organização rigidamente hierarquizada, criar relações de confiança se revela um grande desafio. $O$ trabalho do soldado não se resume ao policiamento na rua, mas é influenciado pelas relações organizacionais, relações complexas onde convivem ao menos duas grandes concepções: o da polícia reativa e repressiva, e o da polícia comunitária. Nem sempre é justa e tranquila a relação de soldados selecionados segundo novos critérios com os oficiais antigos. Nesse sentido, esse descompasso pode afetar profundamente as relações de confiança.

LIÇÕES. Apesar de o artigo se referir a uma instituição pública e a um tipo específico de atividade, pensamos que o tema pode servir de reflexão para os gestores em geral. Guardadas as especificidades de cada organização, a questão do medo e sua aparente ausência podem servir de pista para os gestores que lidam com situações de riscos pensarem uma nova forma de gestão.

No caso dos PMs, os oficiais de visão progressista enfrentam o desafio de conciliar hierarquia e disciplina com uma mentalidade mais flexível e educacionalmente preparada, pondo em dúvida ordens consideradas não compatíveis com a nova filosofia da polícia, de ênfase comunitária. 